\title{
Attorney Role In Fighting Crimes Of Motorcycle Gang In Cirebon
}

\begin{abstract}
Asep Sunarsa ${ }^{1}$
Abstract. Establishment of the motorcycle gang began with the gathering fellow motorcycle enthusiasts, which then turned into a gang of tens or even hundreds of people. Motorcycle gang shaping the lifestyle that sometimes deviate from the norm for the sake of self-adhesive group identity on the streets. The doctrine attached to each self motorcycle gang members were motivated to commit a crime that is very detrimental to the community. Motorcycle gang act according to the standpoint of law, especially criminal law, there are several actions against the law, in the community a lot of evidence that shows that often occurs offense aggravated theft with violence offenses that threaten the lives and physical person.

Keywords: Role of Public Prosecution; Prevention; Criminal Law; Motorcycle gang.
\end{abstract}

\section{Introduction}

The Republic of Indonesia based on Pancasila and the Constitution of 1945 (hereinafter referred to as the Homeland Constitution of 1945), regulate any behavior that citizens can not be separated from all the rules derived from the law. State law requires that the law must always be upheld, respected and obeyed by anyone without any exceptions. It aims to create security, order, prosperity in the life of society, nation and state. $^{2}$

R. Abdoel Djamali argued that the law is not autonomous or independent, the law was not independent of the mutual influence of all aspects that exist within the community. As a rule, the law can establish order and peace in the lives of many people. But in fact unlawful. ${ }^{3}$

The State has two important institutions in an effort to maintain security and order in the country. Both of these institutions are the Indonesian National Army and Police of the Republic of Indonesia. Soldiers assigned to guard the sovereignty of interference originating from outside or the inside. While police in charge of maintaining internal order and security of the country. The role of these two institutions mandated by the Constitution of the Republic of Indonesia Article 30 paragraph (2) which reads: "Enterprises defense and security of the state is carried out through a system of total people's defense and security by the Indonesian military and police forces of the Republic of Indonesia, as the main force, and people as the supporting". 4

Indonesian National Police and the underlying structure as the institution in charge of maintaining internal security and order of the country, in carrying out its duties and

\footnotetext{
${ }^{1}$ Student of Masters (S2) of Law Faculty of Law Unissula Semarang and State Attorney of Cirebon email: asepsunarsa100@gmail.com

${ }^{2}$ Chainur Arasjid 2000 Dasar-Dasar Ilmu Hukum Jakarta: Sinar Grafika p. 54

${ }^{3}$ R. Abdoel Djamali 2005 Pengantar Hukum Indonesia. Jakarta: Raja Grapindo Persada p. 25

${ }^{4}$ The Code of Penal
} 
functions seems not maximized. This can be seen with the internal state of the country are still not completely safe. Indonesia Police Watch reported that in the midst of today's society appears Unexplained motorcycle gang with the anarchy plaguing the society.

The phenomenon of the motorcycle gang crime has become a crime that has become a trending topic and is usually done by teenagers. all crimes committed by motorcycle gangs are very troubling Indonesian society today as the communities Cirebon. Not only minor offenses such as traffic violations, but crimes such as vandalism of public facilities, clashes between the members of a motorcycle gang, persecution until claimed the lives of others, bullying, robbery and many other crimes committed by gangs of bike is already very disturbing the public. ${ }^{5}$

The complexity of the times and changes in outlook on life that happens in all aspects of life in this globalization era, indirectly led to various things in that life. Starting from the positive and negative, as well as the emergence of numerous violations and even crimes in the community. This is a problem which should soon be possible to be resolved, so that the peace and security in the community is maintained and preserved. In the community association, every day there is a relationship between members of the community with one another. The association raises events or occurrences that can move a legal event. ${ }^{6}$

Therefore, security is a right of the citizen. It is clearly stated in the Constitution of the Republic of Indonesia of 1945 Article 28 paragraph (2) which reads: "Everyone has the right to protection of self, family, honor, dignity, and property under his control, and are entitled to a sense of security and protection from threats to do or not do something that is a human right ". 7

Romi Librayanto said the security of citizens must be realized by the state as its internal function. The country's internal functions that maintain public order, tranquility, security, peace in the country and protect the rights of each person. ${ }^{8}$

As one of the human actions that deviate from social norms of human life, crime is a social problem, namely the problems in the community, for the perpetrator and the victim are members of the community as well. Crime will continue to grow in a way that is different even with increasingly sophisticated equipment and modern so that evil will be increasingly disturbing people at this time.

The problem of evil is a perennial problem in the life of mankind, as it develops in line with the development level of human civilization is increasingly complex. The history of human development to date has been characterized by a variety of human effort to sustain life, where violence as one of the phenomena in order to achieve the purpose of a particular group in the community or individuals that are of interest to sustain the life. Relating to crime, violence is complementary to the shape of the crime itself. ${ }^{9}$

\footnotetext{
${ }^{5}$ Indonesia Police Watch. 2013. Anarkisme Geng Motorkembali berlanjut. (http://indonesiapolicewatch.com/). Accessed February 222018

${ }^{6}$ Chainur Arasjid 2000 Dasar-Dasar Ilmu Hukum Jakarta: Sinar Grafika p. 133

${ }^{7}$ Constitution of the Republic of Indonesia Year 1945

${ }^{8}$ Romi Librayanto Ilmu Negara. (Makassar: Refeleksi 2009) p. 123

${ }^{9}$ Barda Nawawi 2001 Arif Masalah Penegakan Hukum dan Kebijakan Hukum Pidana Dalam Penanggulangan Kejahatan Jakarta: Kencana p. 49
} 
Motorcycle gang basically do not have a definitive definition, but the author tries to define that a motorcycle gang is a group of people or groups who use motorcycles as a unifying and usually leads to negative things. The term of this motorcycle gang always gives a bad image which is usually synonymous with anarchy. Lately, the action of a motorcycle gang is increasingly disturbing the public, because of the actions that they did not just a disturbance of public order, for example by performing a wild race but has evolved towards criminal acts such as mugging, robbery, vandalism, assault and even to do murder. Especially in the city of Cirebon, and more specifically.

The rise of motorcycle gangs and juvenile delinquency others must start from the revitalization of the functions in the family. One function of the family must be strengthened is the function of social control. This does not mean a return to the method of "dictator ". As methods of the parents first. But rather give responsible freedom. Freedom given still be restricted from being misused. Show of affection does not mean to fulfill all the demands and wishes of the child. Facilities (right) we give to children must be accompanied by obligations that must be implemented. Thus, we raise our children to be more responsible. Some simple things you can do include applying the method of reward and punishment (reward and punishment). ${ }^{10}$

This of course should be taken seriously, because if we look at what happened in Kalimantan, Bandung, Jakarta and some regions in Java, from time to time more and more criminal acts and crimes committed by motorcycle gangs who ultimately more disturbing people, then before these things happen in the city of Cirebon effective solution must be found in order to eradication.

\section{Research Methods}

The approach used in this study is a sociological juridical approach. Juridical and sociological approach is identify and conceptualize law sesbagai real social institutions and functional in a real life system. ${ }^{11}$ Sociological juridical approach is emphasizing research aimed at obtaining legal knowledge empirically by road directly involved keobyeknya is to know the legal protection against perpetrators of crimes committed by motorcycle gangs in the city of Cirebon.

Qualitative research is a research aimed to describe and analyze the phenomena, events, social activities, attitudes, beliefs, perceptions, thoughts of people individually or in groups. Some descriptions are used to discover and explain the principles that lead to the inference. Qualitative research is inductive. Researcher let problems arise from the data or left open for interpetasi. Data collected by a detailed investigation, includes a detailed description of the context in which those records with the results of in-depth interviews, as well as the results of the analysis of documents and records. ${ }^{12}$ Qualitative research is penelititan which intends to understand the phenomenon of what is experienced by the subject of the study such behavior, perception, motivation,

\footnotetext{
${ }^{10}$ Mulyono 1995 Pendekatan Analisis Kenakalan Remaja dan Penanggulangannya Yogyakarta Kanisius p. 21.

${ }^{11}$ Soerjono Soekanto 1987 Pengantar Penelitian hukum Jakarta: UI Press p. 51

${ }^{12}$ Gempur Santoso 2005 Metodologi Penelitian Kuantitatif \& kuanlitatif Jakarta: Prestasi Pustaka Publisher p. 49
} 
action. Qualitative research has two main objectives, the first of which, describe and reveal (to describe and explore) and both illustrate and explain (to describe and explain). ${ }^{13}$

\section{Results And Discussion}

\subsection{Role In Tackling Crime Prosecutor Carried Motorcycle Gang In Cirebon}

The existence of institutions Attorney of the Republic of Indonesia is Act No. 16 of 2004 on the Attorney (Prosecutor UU). According to the provisions of Article 2 Paragraph (1) of the Prosecutor, stated that the Attorney of the Republic of Indonesia is the government agency implementing state power in the prosecution and other authorities under the legislation. ${ }^{14}$

Attorney is an institution, body, government agency that runs the state power in the prosecution and other authorities. While the people who perform the duties, functions and authority of the so-called prosecutor. This is confirmed in Article 1 Paragraph (1) of the Act the Attorney ie, "Attorney is functional officers who are authorized by law to act as a public prosecutor and the execution of court decisions that have obtained permanent legal force and other authorities under the law". So, it should be stressed that in addition to its work in the field of prosecution, as well as other duly authorized by law, for example as a state attorney, executor of the court verdict has obtained permanent legal force, as certain crimes investigators, and others. ${ }^{15}$

Attorney than as persons with Dominus litis, also is the only criminal decisions implementing agencies (executive ambtenaar). Prosecutor Act strengthened the position and role of the Attorney RI as government state institutions that implement state power in the prosecution. In performing its functions, duties and authorities from the influence of government power and the influence of other powers. This provision aims to protect the profession of prosecutors in carrying out their professional duties.

Crime is a social phenomenon that is constantly faced by every society in the world. Crime in existence to be especially troubling, as it also disturb order and peace in the community do all it can to combat these crimes. Crime prevention efforts have been and continue to be done by governments and society. Various programs and activities have been carried out while continuing to look for most appropriate and effective way to resolve the issue.

In crimes such as theft, they then determine the area of operations, where they are encouraged action on a pride in themselves, when he was able to commit a crime. Based on the results of the examination, general motif motorcycle gangs are stealing because they want to be feared, respected by his gang, and gangs of other motors, they commit the crime of theft for the benefit of the fame of the group, they assume

\footnotetext{
13 Ibid.

${ }^{14}$ Marwan Effendy 2007 Kejaksaan Republik Indonesia Posisi dan Fungsinya dari Perspektif Hukum Jakarta: Ghalia Indonesia p. 127

${ }^{15}$ Suhadibroto. Kualitas Aparat Kejaksaan dalam Upaya Melasanakan Penegakan Hukum.. Paper presented at the workshop organized by the Attorney Monitoring MAPPI FHUI and TIFA Foundation in Jakarta. June 28 to 302004.
} 
that the higher the number of crimes that they make it will be the more popular name of their group. There is one group of motorcycle gangs in the city of Cirebon.

The role of the prosecutor in tackling crimes committed by motorcycle gangs in cooperation with the police and counseling to school children by sending representatives from the police to be a builder ceremony at schools in the city of Cirebon in turn, counseling is particularly important given member a motorcycle gang in the area of Cirebon city is generally a student, it is very useful if the student is given an understanding of the acts that constitute a criminal offense or a criminal act. The provision of extensive and detailed explanations to the students about some juridical aspects that are relevant to mischievous deeds are often done by teenagers,

Furthermore, in addition to counseling the police and prosecutors to patrol in areas that are considered prone to crimes committed by motorcycle gangs. Police officers must be able to detect as early as possible, if there are associations in the community, which can compromise the security and public order, khsusunya association on behalf teenagers their association as "motorcycle gang" whose actions are often disturbing the public. These patrols aim to anticipate all deceit ability criminals increasingly rising especially for crack and anticipate the crimes committed by motorcycle gangs will maximize the combined forces patrol the block, block by the police patrol was conducted to determine how social and cultural circumstances, diketahuilah routines so that people in one place that ultimately, if one day find things that are outside the customs area, it will soon be known, and easy to tackle crime in the region. So that people can feel safer and feel the protection and legal certainty for himself.

\subsection{Factors Of Motorcycle Gang Action Occurrence Particularly in Cirebon}

As described earlier that the causes of the crimes committed by motorcycle gangs, have many criminologists argue that crime is the result of several factors both internal and external self-offenders. There should be an inquiry or research that can provide answers on the causes or factors that can affect a person committed a crime, in this case the crimes committed by motorcycle gangs particularly in the city of Cirebon in January-December 2017.

One of the main reasons why adolescents choose to join a motorcycle gang is a lack of attention and affection of parents. This could be due to too busy both parents to work, so that the attention and affection to his son only expressed in the form of material. Though the material can not change their thirst for love and attention from their parents.

Basically everyone wants recognition, attention, praise and affection on the environment. Especially from parents or family, as natural parents or family have a very strong emotional bond. This was disclosed by Mr. Renaldy (Cirebon Police Chief) that at the time of recognition, attention, and affection of parents do not they (teens) get at home, they will seek it elsewhere. One of the easiest places to get the recognition they found it was in the neighborhood peers. Ironically, often negative 
activities of choice children of a broken home as a way to gain recognition of their existence. ${ }^{16}$

Furthermore, based on interviews with the Cirebon police chief, Tri Hambodo say that the tradition of urban life tend to attach great importance to and takes his job alone. Therefore, the material is very important for those who have the character of "not easily satisfied" that drained the acceleration time job so concerned with family matters in this notice and give affection to their children is reduced. Finally. Child feel less attention and feel less given affection.

He added that the family is the first institution that should provide education related to social values, culture and religion are strong. If the parent is not enough time to give provisions of religious values, for example, parents can cooperate with a cleric or chaplain to technically provide religious education.

\section{Closing}

\subsection{Conclusion}

Motorcycle gang is a group of people have a hobby of motorcycling that make motorcycle riding activities together both objectives convoy and touring motorcycle. There are also those who argue that the motorcycle gang is a group of people or groups who use motorcycles as a unifying and usually leads to negative things. The term of this motorcycle gang always give a bad image which is usually synonymous with anarchy, in contrast to a community is a group of people who have the same hobby, namely automotive enthusiasts, motorcycle community usually gathered with the same vehicle, and more specifically in terms of the type of bike.

The negative impact of many motorcycle gang mentioned that would create traffic disrupted, it can also lead to social unrest if the motorcycle gangs commit acts that are negative. The motorcycle gang is actually arose from a tendency of the same hobbies. Understanding the inherent motormemang gang violence, it is because some motorcycle gang has recently been transformed from a collection of motorcycle riding hobby a hobby persecute, hobbies commit robbery and murder.

Crime is the behavior of someone who violated the positive law or law that legitimized the enactment of a negara.Kejahatan present in the community in a variety of models of behavior has been defined legally as an offender, and is prohibited by law and determined by the court that does have binding legal force.

Laws in function to control all aspects of national and state can give the maximum contribution to the implementation of development if the law enforcement community and all levels of submission and obedience to the rule of law, but not all of the elements in the society is ready to obey the rules that exist. Hence arises an unlawful act such as homicide.

Motorcycle gang crime last few years is rife in Indonesia, especially in the city of Cirebon, this indicates that the mode of crime is increasing. Motorcycle gang crime more often than robbery and murder, and most perpetrators are students or people

\footnotetext{
${ }^{16}$ Results of an interview with Mr. Renaldy MH Cirebon police leadership
} 
who drop out of school. The rise of the action of this motorcycle gang give great attention to the community because many actions undertaken by motorcycle gangs plaguing the society and against the law.

\subsection{Suggestion}

- Improving the system of oversight by any law enforcement, including the role of the prosecutor to prevent criminal acts.

- Other law enforcement with the cooperation between the police held denagn prosecutor to further improve reprensif and preventive measures.

- Increased legal counseling to equalize the legal awareness to the community terkhususnya for residents in the city of Cirebon.

\section{Bibliography}

[1] Akbar Ade Putra Tinjauan Yuridis Terhadap Tindak Pidana Pembunuhan Yang Dilakukan Oleh "Anggota Geng Motor" di Kota Cirebon (Tanggapan Atas Putusan No. 530/Pid.B/2014/PN.Mks) Makasar: Fakultas Hukum Universitas Hasanuddin 2015

[2] Alam A.S. 2010 Pengantar Kriminologi Cirebon: Pustaka Refleksi Books.

[3] Arief Amrullah 2006 Kejahatan Korporasi Malang: Bayumedia

[4] Barda Nawawi 2001 Arif Masalah Penegakan Hukum dan Kebijakan Hukum Pidana Dalam Penanggulangan Kejahatan Jakarta: Kencana

[5] Chainur Arasjid 2000 Dasar-Dasar Ilmu Hukum Jakarta: Sinar Grafika

[6] Gempur Santoso 2005 Metodologi Penelitian Kuantitatif \& kuanlitatif Jakarta: Prestasi Pustaka Publisher

[7] Imam Fadly Alif Utama 2016 Tinjauan Kriminologis Terhadap Kejahatan Tindak Pidana Remaja Geng Motor di Kota Cirebon Perspektif Hukum Islam (Studi Kasus Polrestabes Cirebon) Makasar: Hukum Pidana Dan Ketatanegaraan Fakultas Syari'ah Dan Hukum Universitas Islam Negeri Alauddin

[8] Indonesia Police Watch. 2013. Anarkisme Geng Motorkembali berlanjut. (http://indonesia-policewatch.com/). Accessed on 22 Pebruary 2018

[9] Ismail Rumadan 2007Krimonologi Studi Tentang Sebab-sebab Terjadinya Kejahatan Yogyakarta: Graha Guru

[10] M. Husein Harun 2005 Surat Dakwaan Teknik Penyusunan Fungsi dan Permasalahannya Jakarta: Rineka Cipta

[11] Mulyana Kusumah 2001 Aneka Permasalahan Dalam Ruang lingkup Kriminologi Bandung: Alumni

[12] Mulyono 1995 Pendekatan Analisis Kenakalan Remaja dan Penanggulangannya Yogyakarta Kanisius

[13] Qirom Meliala dan Sumarsono 2005 Kejahatan anak Suatu Tinjauan Sosiologi dan Hukum Yogyakarta: Liberty

[14] R. Abdoel Djamali 2005 Pengantar Hukum Indonesia. Jakarta: Raja Grapindo Persada

[15] Romi Librayanto 2009 Ilmu Negara. Cirebon: Refeleksi 
[16] Romli Atmasasmita 2010 Teori dan Kapita Selekta Kriminologi Bandung: PT. Refika Aditama.

[17] Rusli Effendy 2006 Asas-Asas Hukum Pidana Ujung Pandang: Loppen UMI

[18] Soerjono Soekanto 2003 Kriminologi Sebab dan Penanggulangan Kejahatan Jakarta: Sinar Grafika.

[19] Suharsimi Arikunto 2004 Prosedur Penelitian suatu Pendekatan Praktek Jakarta: Bina Aksara

[20] Sunaryati Hartono 1994 Penelitian Hukum di Indonesia Pada Akhir Abad ke- 20 Bandung Alumni 